\title{
PERSPECTIVE
}

\section{COVID 19 pandemic: Lesson learned by South Korea and its application with} India's perspective

\section{Smita Sinha ${ }^{1}$, Rishita Chandra ${ }^{2}$}

${ }^{1}$ Associate Professor, Department of Community and Family Medicine, All India Institute of Medical Sciences, Rishikesh; ${ }^{2}$ MPH Student, School of Public Health, All India Institute of Medical Sciences, Rishikesh, Uttarakhand.

\begin{tabular}{|l|l|l|l|l|l|l|l|}
\hline Abstract & Introduction & Methodology & Results & Conclusion & References & Citation & Tables / Figures \\
\hline
\end{tabular}

\section{Corresponding Author}

Dr Smita Sinha, Associate Professor, Department of Community and Family Medicine, All India Institute of Medical Sciences, Rishikesh, Uttarakhand - 249203

E Mail ID: smita.maiid@gmail.com

\section{Citation}

Sinha S, Chandra R. COVID 19 pandemic: Lesson learned by South Korea and its application with India's perspective. Indian J Comm Health. 2020;32(3):608-609.

Source of Funding: Nil Conflict of Interest: None declared

\section{Article Cycle}

Received: 25/07/2020; Revision: 05/08/2020; Accepted: 05/09/2020; Published: 30/09/2020

This work is licensed under a Creative Commons Attribution 4.0 International License.

\section{Introduction}

A novel coronavirus named as severe acute respiratory syndrome coronavirus 2 (SARS-CoV-2) emerged in December 2019, in Wuhan city of Hubei province of China, which got transmitted throughout the nation and even world. It was declared as a Public Health Emergency by WHO on January 30th 2020, due to the increase in the number of cases reported from various regions of WHO with the evidence of human to human transmission. (1)

Spread of COVID-19 across the globe: China reported first COVID-19 death on January 11th 2020. After a few weeks, 830 cases were diagnosed in China along with 26 reported deaths. By January 20, Wuhan was placed under lockdown and China alerted other nations about its spread in various provinces. (2)

This contagious disease had spread to 24 nations outside China-Hong Kong-Macau, by 2nd February. About 172 countries and regions were engulfed by this virus by March 25, 2020. (3) Globally over 3,308,643 cases have been confirmed, over 234,123 deaths have been reported, and around 1,042,981 have recovered as on 30th April 2020. (4)

Controlling the Pandemic COVID 19: success story of the Republic of Korea: Initially, one country which successfully stood out from the rest of the world was South Korea. The country confirmed its first few cases in late January and then reported a surge in the cases a few weeks later. The country was exploded with cases in dozens to hundreds to thousands during late February and early March and launched drive-through testing centers and massive contact tracing.

Almost 909 new cases were identified in a single day of February 29th 2020 and was reported at peak. This data brought the country with 50 million population on the verge of a deluge. But the number of new cases was halved within a time period of just a week. The number of cases reduced to half within four days, and it halved, again the following day. (5)

On March 23, only 64 new cases were reported by South Korea, which was lowest in nearly a month. At the same period, other countries were struggling with this disease as cases continued to soar in multiple of hundreds and thousands daily. Huge surge in cases had not devastated the health care system only but collapsed the economy also. Italy recorded hundreds of deaths daily; South Korea kept it below eight in a day. (6)

Alongside China, South Korea stood out to be one of the countries with large outbreaks that successfully flatten the epidemiological curve, without any draconian policy or lockdown.

Lessons learnt from South Korea: With a comprehensive Coronavirus response, the country followed the systematic strategy of 3Ts i.e. Test, Track and Trace. South Korea made effective use of information and communications technology to combat the pandemic. The testing program implemented by Korea was one of the massive, 

expansive and well-organized program worldwide. Korea combined this program with meticulous efforts to isolate infected people and robust contact tracing. They effectively put all the contacts in quarantine.

Approximately 2,70,000 people were tested in Korea at the rate of 5200 tests per million inhabitants by midMarch 2020. South Korea utilized the lessons learnt from MERS and successfully flattened the curve. $80 \%$ of the cases were in Shincheonji cluster and contact tracing started after quarantine. South Korea also announced a penalty of $2500 \$$ on quarantine violators. South Korea reflected a strong action plan for cluster transmission and also issued special entry procedures including travelers by ship. Mass media e.g. Television, smartphone alerts, station announcements for advertising on social distancing, reminders for wearing masks, websites and apps were streamlined to collect and map the data with attentive public response. (7)

COVID 19 Control: India's perspective: In a country like India, managing this pandemic in such a large population seems challenging. The measures taken by South Korea is not only inspiring but shows the way towards success also. But is it possible to apply the model of South Korea when healthcare infrastructure of India is taken into consideration?

The biggest challenge in India's COVID 19 containment plans seem to be the overstretched and under-invested Public health care sector. The Government of India spends around $1.5 \%$ of its GDP on health, which is considered to be one of the lowest in the world. The private sector is the main tributary of health care for many households in urban and rural areas. (8)

COVID 19 treatment is currently being sprung up in government hospitals. These hospitals have been underfunded and overburdened in most part of the country. In this scenario, the strategy of extensive testing seems difficult.

In such situations social distancing, self-quarantine, home isolation and lockdown can prove to be the best way to contain this pandemic in India.

On March 22, the government of India announced a nation-wide lockdown. The first phase of 21 days lockdown in India helped reduce the number of symptomatic COVID 19 cases below projection but following the rise in the number of cases the lock down was extended till May 31st 2020. It may have proven helpful in flattening the curve of COVID 19. (9)
The main goal of lockdown towards flattening the curve was to minimize the number of cases, getting a window period to gain more opportunities for interventions to contain the disease. The lock down aimed to provide meantime to come up with innovations and reduce the burden on the healthcare system.

\section{Conclusion}

The risk of coronavirus in India was low initially. When the lockdown was enforced in the beginning, India was in phase II of COVID 9 outbreak with the disease spreading to close contacts with no evidence of community transmission. But the trajectory of cases changed in the next few weeks and it has been extended. Therefore, apart from restraining this outbreak, efforts should be made to formulate comprehensive measures to prevent any such outbreaks in future.

\section{References}

1. Statement on the second meeting of the International Health Regulations (2005) Emergency Committee regarding the outbreak of novel coronavirus (2019-nCoV).Geneva : World Health Organization.2020 Available from: https://www.who.int/

2. WHO Novel Coronavirus (2019-nCoV) situation report-1 (21 January 2020). Geneva: World Health Organization.2020. Available from: https://www.who.int/docs/defaultsource/coronaviruse/situation-reports/20200121-sitrep-12019-ncov.pdf

3. WHO Novel Coronavirus (2019-nCoV) situation report-5 (25 January 2020). Geneva: World Health Organization.2020. Available from: https://www.who.int/docs/defaultsource/coronaviruse/situation-reports/20200125-sitrep-52019-ncov.pdf

4. WHO Novel Coronavirus (2019-nCoV) situation report-101 (30 April 2020). Geneva: World Health Organization.2020. Available from: https://www.who.int/docs/defaultsource/coronaviruse/situation-reports/20200430-sitrep-101covid-19.pdf

5. WHO Novel Coronavirus (2019-nCoV) situation report-40 (29 February 2020). Geneva: World Health Organization.2020. Available from: https://www.who.int/docs/defaultsource/coronaviruse/situation-reports/20200229-sitrep-40covid-19.pdf

6. Ministry of Health \& Welfare : News \& Welfare Services > Press Release View Content [Internet]. Available from: https://www.mohw.go.kr/eng/nw/nw0101vw.jsp

7. Ministry of Health and Welfare- Republic of KoreaCoronavirus. Coronavirus disease 19(COVID-19) [Internet]. Coronavirus disease 19(COVID-19). Available from: http://ncov.mohw.go.kr/en/

8. Duggal R. Health care utilisation in India. Health Millions. 1994Feb;2(1):10-2. PMID: 12288588.[PubMed].

9. National Portal of India [Internet]. Available from: https://www.india.gov.in/news_lists 